\title{
Naar aantrekkelijker vervolgopleidingen in de sociale geneeskunde
}

\author{
Joost van der Gulden
}

(C) Bohn Stafleu van Loghum is een imprint van Springer Media B.V., onderdeel van Springer Nature 2018

\section{Sleutelen aan de sociaalgeneeskundige vervolg- opleidingen}

De wereld staat niet stil. Inzichten, mogelijkheden en verwachtingen veranderen. Dat geldt ook voor het medisch onderwijs. Vanwege vakinhoudelijke en onderwijskundige ontwikkelingen is het nodig om de leerdoelen van een opleiding periodiek bij te stellen en te bekijken wat aan vernieuwing toe is. In de afgelopen jaren is zo gesleuteld aan de sociaalgeneeskundige vervolgopleidingen. Het doel is om basisartsen die arts maatschappij \& gezondheid, verzekeringsarts of bedrijfsarts willen worden een aantrekkelijke en uitdagende opleiding te bieden, waarin ze zich de competenties en 'kritische beroepsactiviteiten' kunnen eigen maken die kenmerkend zijn voor hun discipline.

Hoe dit moet worden aangepakt is op hoofdlijnen vastgelegd in Landelijke opleidingsplannen (LOP's). De opleidingsinstituten (NSPOH, SGBO, TNO) en de organisaties waar sociaalgeneeskundigen worden opgeleid (GGD'en, UWV, arbodiensten) beschrijven in eigen opleidingsplannen hoe ze het cursorisch onderwijs en de praktijkscholing willen vormgeven en op elkaar afstemmen. In de nieuwe opleidingsvisie krijgt de praktijkopleider die artsen in opleiding (aios) superviseert een grotere rol. Daarom is ook een Landelijk Professionaliseringsplan Praktijkopleiders (LPP) vastgesteld. Aan 'toetsenboeken' met instructie voor de beoordeling van aios wordt nog gewerkt. Bij al deze ontwikkelingen geldt de 'Kwaliteitsvisie Opleidingen en Raamplan Sociale geneeskunde’ (KOERS), waaraan al eens een redactioneel in TSG is gewijd als achtergronddocument [1].

J. van der Gulden $(\bowtie)$

SGBO - opleiding tot bedrijfsarts en verzekeringsarts,

Radboudumc, Nijmegen, Nederland

joost.vandergulden@radboudumc.nl

\section{Leer-werkbedrijf}

De essentie van deze plannen laat zich als volgt samenvatten. De organisaties waar sociaalgeneeskundigen worden opgeleid moeten het karakter krijgen van een leer-werkbedrijf. Nu ligt het accent nog te veel op de productie en is opleiden daaraan ondergeschikt. Werkgevers in de sector moeten daarom in instellingsopleidingsplannen laten zien dat ze een veilig en uitdagend opleidingsklimaat garanderen, waarin artsen in opleiding (aios) en hun praktijkopleiders voldoende tijd krijgen voor opleidingsactiviteiten en leergesprekken. De taken en activiteiten van de aios in hun dagelijks werk moeten bovendien beter aansluiten op het cursorisch onderwijs.

Van veel activiteiten en situaties in het dagelijks werk valt overigens best een leeractiviteit te maken. Maar je moet de mogelijkheden dan wel herkennen en aangrijpen. De praktijkopleiders spelen hierin een belangrijke rol. Zij krijgen ook een grotere verantwoordelijkheid in het toetsen en beoordelen van de aios. Daarnaast wordt verwacht dat zij vaardiger worden in het coachen en ondersteunen van aios in hun persoonlijke en professionele ontwikkeling, en niet alleen insteken op de overdracht van kennis en vaardigheden. Deze grotere aandacht voor coaching zien we ook in de vervolgopleidingen in de curatieve sector [2].

Een valkuil bij de plannen om de opleiding uitdagender te maken is dat het hierbij nog te veel gaat om nieuwe opdrachten en leeractiviteiten, waarover een reflectieverslag moet worden geschreven. Veel aios ervaren deze verslaglegging en 'portfoliodruk' echter meer als last dan als lust. Het is zaak naar effectieve onderwijsvormen te zoeken die meer aanspreken. 


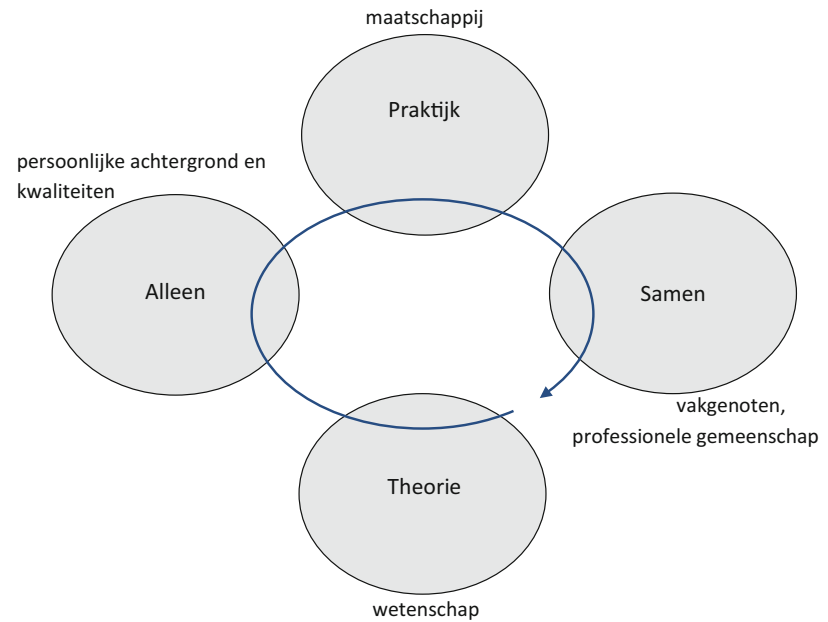

Figuur 1 Referentiepunten en inspiratiebronnen voor professionele ontwikkeling

\section{Leren doe je samen}

In de verschillende documenten over onderwijsvernieuwing is een ruim aantal verbeterpunten te vinden. Onze aandacht moet echter niet alleen gericht zijn op het verbeteren op onderdelen, maar vooral ook op het bereiken van meer samenhang tussen de afzonderlijke elementen in het onderwijs. Een simpel schema dat ik vond in een publicatie van Manon Ruijters, hoogleraar Learning, development and behavioral change aan de Vrije Universiteit, kan hierbij houvast bieden. $\mathrm{Zij}$ benoemt verschillende inspiratiebronnen voor de ontwikkeling van professionals [3]. Pas wanneer al deze bronnen evenwichtig worden benut, is sprake van effectief leren. Ruijters maakt hierbij onderscheid tussen Theorie en Praktijk, maar ook tussen Alleen en Samen (zie fig. 1).

Het eerste onderscheid betreft het spanningsveld tussen theoretische inzichten en praktisch handelen. Van professionals wordt verwacht dat ze evidencebased leren werken, dat wil zeggen dat ze hun handelen zo veel mogelijk baseren op wetenschappelijke kennis en theorievorming, samengevat in richtlijnen en protocollen. In hun dagelijks werk ontdekken ze dat dit lang niet altijd lukt en dat het dan nodig is om zelf een adequate oplossing te kiezen op basis van professionele inzichten en werkervaring. De noodzaak om geregeld een keuze te maken kan zeker in de opleidingsfase tot dilemma's leiden: wat laat ik prevaleren wanneer theorie en praktijk wringen? Juist het duaal leren, de combinatie van praktijkscholing en cursorisch onderwijs, helpt de aios bij het leren maken van zulke afwegingen.

\section{In gesprek met elkaar}

Ruijters benadrukt dat de dialoog met anderen hierbij een belangrijk leermiddel is. Ze ziet het 'samen' uitwisselen van gedachten en ervaringen tussen vak- genoten als voorwaarde voor de professionele ontwikkeling van individuen, maar ook van de beroepsgroep als geheel. In gesprek met elkaar wordt geleerd van casuïstiek en wordt duidelijk wat nieuwe theoretische inzichten voor de praktijk betekenen. Dit aspect is herkenbaar in het samen leren in een vaste cursusgroep: tijdens groepsdiscussies, oefeningen en casusbesprekingen. Maar ook tijdens gesprekken met groepsgenoten en docenten buiten het formele contactonderwijs. Samen leren vindt ook plaats tijdens het contact met de praktijkopleider en andere collega's op de werkplek, informeel of gepland tijdens werkoverleg of intervisie.

Zeker in de opleidingsfase leert een professional ook 'alleen': tijdens zelfstudie, individuele opdrachten, enzovoort. Maar ook wanneer hij of zij probeert om dat wat tijdens een cursusdag aan de orde kwam, zelf in praktijk te brengen. Lukt dat? Wat levert het op?

Een ander aspect van 'individueel leren' is dat artsen verschillen in leerstijl, eerdere werkervaring, kernkwaliteiten, waarden en normen, communicatieve vaardigheden en analytisch vermogen. Meer dan voorheen wordt onderkend dat aandacht voor de individuele en professionele ontwikkeling van de aios een essentieel aspect is van een medische vervolgopleiding [2].

\section{Leercyclus}

Centraal in fig. 1 is een pijl te vinden die een draaibeweging of cyclus suggereert. Juist deze pijl laat zien wat de beoogde onderwijsvernieuwing wil bereiken. Onderwijs is het meest effectief wanneer het lukt alle genoemde referentiepunten en inspiratiebronnen met elkaar te verbinden. Nieuwe kennis draagt pas bij aan professionele ontwikkeling wanneer een aios zich afvraagt hoe hij deze kan toepassen, dit eens probeert en vervolgens zijn ervaringen deelt met vakgenoten.

Een voorbeeld: tijdens een cursusdag wordt het ICF-model behandeld. Margot probeert vervolgens of dit model een bruikbaar kader biedt om alle relevante informatie uit te vragen tijdens een spreekuurcontact. Dit blijkt nog best lastig. Zij bespreekt dit met haar opleider en daarna met enkele van haar maatjes uit de cursusgroep. Deze gesprekken geven haar houvast om het op een wat andere manier te proberen. Wanneer de ICF op een van de volgende cursusdagen opnieuw aan de orde komt, pikt ze weer het nodige op. Theorie en praktijk, alleen en samen leren brengen haar zo verder.

Opleiden betekent zo een veilige sfeer scheppen waarin mensen nieuwe stappen durven te zetten en hun ervaringen kunnen delen om daarvan samen te leren [2]. Opleiden vraagt van alle betrokkenen dat ze elkaar als partners zien en willen samenwerken om tot een goed resultaat te komen [3]. Opleiden vraagt om het intuïtieve vermogen om informele leermomenten te benutten wanneer die zich voordoen. Maar oplei- 
den vereist ook een planmatige aanpak. De leercyclus die door de pijl wordt uitgedrukt, komt immers niet vanzelf tot stand. Dat vraagt de nodige voorbereiding en afstemming. De onderwijsdocumenten die de afgelopen jaren zijn geschreven, bieden hiervoor een goede basis.

\section{Literatuur}

1. Gulden J van der. Controle is goed, vertrouwen is beter. Tijdschr Gezondheidswet. 2015;93:281-2.

2. Leede B de, Rooijen C den. Het coachboek voor opleiders. Coachen als begeleidingsstijl bij het opleiden van artsen in opleiding tot specialist. Leiden: DeTweedePraktijk; 2016.

3. Ruijters MCP. Queeste naar goed werk. Over krachtige professionals in een lerende organisatie. Deventer: Vakmedianet; 2018. 